\title{
The Second Constitutional Monarchy Period Which is an Important Milestone in Turkish Political Traditional: Power, Politics, Bureaucracy*
}

Zübeyir BARUTÇU

Assist.Prof.Dr.

Ahi Evran University

Faculty of Economics and Administrative Sciences

Political Sciences and Public Administration

zubeyir_barutcu@hotmail.com

Abstract

The second constitutional monarchy period is an important milestone in both the customs and legacies it handed down to Turkish political culture and the specific characteristics of the period. The movement which a group of enlightened people and especially the young Turks lead made II.Abdülhamit declare the constitutional monarchy in 1908. From this point of view, we can say that the constitutional monarchy is the most comprehensive democratic movement in the Ottoman State. However, for the Young Turks who were the founders of freedom, the problem of saving the country rather than freedom was the main aim of their politics. The second constitutional monarchy is the first sample of multiparty system. With the collapse of monarchy, a constitutional system was formed and political parties which are indispensables of democracy were established. This inevitably contributed the development of democratic culture in power/opposition conflict. But, this disagreement focused "intolerance" in politics rather than increasing the ability of conflicting culture acceptance. An important aspect of the second constitutional monarchy is that it passes the strong burocracy tradition on commonwealth burocracy. This situation has closely impressed Turkish state tradition. Another issue that makes the period important is the thoughts and actions of Young Turks. in the direction of this data, rather than what the second constitutional monarchy has brought, how this return has affected the political power tradition in view of political heritage and in what aspects it has influenced the burocracy and democracy tradition have been aimed in this study. Several scientific sources related to the topic have been searched and a point of view has been reached in order to reach this aim.

Keywords: Power, politics, the second constitutional monarchy, burocracy, soldier.

\section{Introduction}

The second constitutional monarchy period has an exceptional place in the Turkish political history. Civil-military relations, which was shaped by the intervention of the soldier to the civil power, has almost become a class by getting more central with the new citizen type tried to be formed within the axis of westernization and 1908 bureaucracy impact getting its power from the reforms. Besides, the Young Turk intelligentsia has moved away from the public by trying to fold the public to the direction it wished. However, among the important events of the period, there are the fights of statist elites against the political elite and the Committee of Union and Progress (CUP) that was remarkable in the period and the solution suggestions used or applied by Young Turk intelligentsia for saving the empire. Therefore, we cannot assess the events occurred during the second constitutional monarchy period as events which were lived and finished in that period. Indeed, its effect to the Turkish political history and the history of republic is undeniable.

The statist braw understanding powered by the military custody occuring after that period had seen the environment or public as an organism which must be converted, by moving the center from the environment day by day. Relations of political power and political opposition was built on intolerance and it has kept on a continuously stressing plane. As the understanding of excessive state became more decisive in individual-state relations, the Western concept of democracy has become authoritarian/guided democracy by mutating in the hands of bureaucratic elites. At the end, the fact that the republic period used many concepts or thoughts belonging to the second constitutional monarchy and the continuation of the second constitutional monarchy bureaucracy by being transferred to the republic bureaucracy and the deterioration of state-public relations against the state can be seen as the important heritages left by this term to the political culture.

* Project Code: PYO-IKT.4010.14.010, this study is supported by Ahi Evran University BAP Unit 
In this study, CUP's democracy understanding, its relations with the public, its view of public as a lumpen by moving away from the environment and the approaches of public engineering of intelligentsia and lastly the applications of bureaucratic elitist paradigm and its relations with the opposition will be expressed generally.

\section{Democracy, Public, Intelligentsia and Bureaucracy}

The second constitutional monarchy, which was announced by Abdulhamid with the struggles of CUP, gives the first sample of a multi-party system. A constitutional environment was created with the overthrow of monarchy and the political parties that are indispensable for democracy started to come out one by one. This situation inevitably brought the conflicts of political power and political opposition and contributed the development of democratic culture. Many parties were founded in this period and their common point has been the Liberty and Entente Party (LEP). The ultimate purpose of LEP is to make CUP far from the power.

The discourse that the power was taken in an illegal way and the other reasons were enough for the opposition to grind against the power. At the same time, the fact that the power deemed itself as the only owner of country and it legalized its actions on behalf of the salvation of country caused the opposition get increasingly stiffened against the power. Indeed, CUP was exposed to great pressures in the elections in 1912. 1912 election, which were made with open vote-secret counting, is known as "the sticked election" because of this reason. From this perspective, the confrontational culture has placed the concept of "intolerance" to the focus of politics rather than improving its ability to digest politics.

Completely different ideological paradigms of power and opposition has made the relations more brittle. CUP, which was leaded by positivist Ahmet Rıza, and the LEP, which was leaded by Prince Sebahattin's decentralist thoughts, thought in different ways as the salvation prescription. Ahmet Rıza was for centralism and Muslim-Ottoman nationalism and against all kind of foreign interventions made to the Ottoman Empire. By contrast, Prince Sabahattin was for a decentralist government that gives as much place as possible for the private enterprise which he deemed as an important factor for development. He was not against the commercial enterprises and political interventions to be made to Ottoman Empire for accelerating the development. Ahmet Riza and his friends were opposing this idea in a relentless way and the separation between his and Prince Sabahattin's groups started to be clear as one of the separations between Turkish nationalism and Ottoman Liberalism (Lewis, 1993). Indeed, the conversion of Turkism into the Turkish nationalism happened with the Committee of Union and Progress. However, as the Committee of Union and Progress could not stand for the liquidation of the Ottoman Empire, it had to be extremely cautious in this case and it kept its purpose hidden from even itself for a long time (Akşin, 1998).

In reality, there was a political activism aiming to save the state rather than an economic program on the foreground of Young Turk idea. The main purpose of Young Turks was to save the Ottoman State's autonomy and geographical integrity against its gradual fragmentation (Keyder, 1993). Tanör (1999), just like Keyder, says that the main purpose of Young Turks was to save the Empire rather than freedom, because there will be less nations separating from the Empire in a regime in which there are freedom and justice. Thus, to establish a modern management by ending II. Abdulhamid's absolutism and to give political rights and justice to all regardless of their religions were deemed as the only way to ensure the State's survival (Akşin, 1987). Therefore, the intelligentsia, who were scattered, combined in particular publishing organs and they sought for solutions to prevent the ending of Ottoman Empire. Political thought flows confronted us for the first time because of this reason. A bundle of thoughts emerged when the interminnent thought in the country were added to the thoughts imported by Young Turks who were attracted to the Western culture. in General, Westernism, Islamism, Turkism and Socialism appear to be the popular thoughts of the second constitutional monarchy period.

Concepts like positivism, constitutionalism and populism created the main elements of Young Turk bureaucracy which represented a centralist bureaucratic staff strengthening with the reforms. So it was necessary to take science and technology of the West to save the state and to transform the public in accordance with this new formation. At this point, the mission of Young Turk intelligentsia was to bring light to the public and teach them what is good or bad (Hanioglu, 1986). The Young Turk intelligentsia deemed the intelligentsia obliged and required to transform the public by seeing it as an organism. This positivist perspective used to create intelligentsia theory constantly and legalize their actions (Kahraman, 2010). Heper (2006) emphasizes that there bureaucratic elites had an utopian thought and they believed that they could create a future in this way by dreaming a fictional future just because they want so.

The Young Turks used to be consistent of both the intellectuals who studied in foreign schools and effected from the foreign thoughts and the bureaucrats who took higher education in modern schools in the country. Therefore, they used to think that the education of the public was necessary for the salvation of the country. However, as they could not get the expected support from the public for long years, the public became unreliable for them. in this context, ideology of populism of the 
Young Turks reflects the idea that the educated people should bring light to the public, so they should try to adopt their own 'rights' to the public rather than a democratic and liberal aspect (Köker, 1993). in other words, their relations with the public could not go further than educating it by publishing and calling them to be vigilant against the acts causing due to the Armenian issue (Petrosyan, 1974).

CUP staff used the power of military and government bureaucracy for taking the power rather than taking the support of people, because of this, the revolution in 1908 was the victory of bureaucracy and intelligentsia hierarchy (Karpat, 2012). At the same time, CUP, which could not get any support from the public during modernization, was always alone and was the representative of the bureaucratic intelligentsia, understood that taking the power with the revolution in 1908 did not mean to take the public (Gevgilili, 1990). As mentioned above, this case caused anger and rage against the public and CUP referred to Populism, which was produced and built by them, to show that they were not against the public. Naturally, this kind of populism is a concept in which the bureaucratic intelligentsia decides on behalf of the public and deems it legitimate rather than a concept demanded and used by the public itself (Heper, 1974) Thus, the tradition to be separated from the public, started by the bureaucracy of reforms, continued and developed by the bureaucracy of CUP.

CUP, which was remarkable in the period and had the political power, was far from being a typical political party as its structure was mainly consistent of civil-soldier bureaucrats. This elitist/bureaucratic structure of CUP will take its relations with both the political parties and the public in a traumatic plane. This case resulted the raise of opposition after July 1908 and the transition of CUP into an attitude that we can call 'authoritarian democracy' (Cavdar, 1999). Indeed, the bureaucrats of CUP got closer to despotism day by day for raising its share in the economy when they had the power (Küçükömer, 1994) and against the possibility that the public or opposition would get stronger with the liberalist policies, bureaucrats such as Murat and Ahmet Riza Bey, who told the military medicals that the situation is not like they think, suggested to be the leader for the public and believed that the public did not have place in the unit to be established, started the progress of separation from the public at the beginning especially after the second constitutional monarchy (Mardin, 1992). Naturally, CUP bureaucrats that are attracted to the Western culture understood that that were not ready to take the power of such cosmopolitan society when they took it, however this situation accelerated them to rotate through domination day by day (Tunaya, 2004).

Role and efficiency of civil-soldier bureaucracy and Ottoman-Turkish politics in which some of the intelligentsia can be included increased in parallel with the corporisation of modernization struggles by getting more common and they became the main actor of modernization of bureaucracy which confronted us as a class in time (Kaliber, 2007). Bureaucratic centralism and bureaucratic oligarchy and the Ottoman Empire's excessive state understanding, which started with the reforms, took a more solid appearance in the hands of Young Turk intelligentsia which built the second constitutional monarchy. However, the free did not have much meaning for CUP whose main purpose was to save the country. Actually it is very hard to say that they did contribution to the freedom except the re-announcement of the Ottoman Basic Law. Indeed, the facts that they did not take serious the actions which were not created by them, they did not have the principles to determine their future and they thought that the collective discipline was superior than the individualism and the policy must be kept under a central/oligarchic control, are important in terms of their determination for the future (Ahmad, 1995).

\section{Conclusion}

The second constitutional monarchy period has remarkably effected the coming periods with its features such as the creation of power-opposition culture, weakening of center's link with the environment, the public's transition within Westernization, the new citizen type, pressure of the military on the power, positivism which was tried to be built on the Ottoman tissue.

At the same time, we can say that the second constitutional monarchy period was maybe the most serious democratic breakthrough in Ottoman state. It can be seen that political parties were created, different ideas were expressed and important developments in constitutionalism were made within the polyphony brought by it, even if it is not in the Western sense. Ultimately, we can say that; the second constitutional monarchy period has deeply influenced the Turkish political traditions with its events and thoughts (positive or negative).

\section{References}


[1] Ahmad, Feroz (1995). İttihat ve Terakki 1908-1914. İstanbul: Kaynak Yayınları, 191-192.

[2] Akşin, Sina (1987). Jön Türkler ve İttihat ve Terakki. İstanbul: Remzi Kitabevi, 28.

[3] (1998). Türkiye'nin Yakın Tarihi. Ankara: İmaj Yayıncılık, 75.

[4] Çavdar, Tevfik (1999). Türkiye'nin Demokrasi Tarihi 1839-1950. Ankara: İmge Kitabevi, 100.

[5] Gevgilili, Ali (1990). Türkiye'de Yenileşme Düşüncesi, Sivil Toplum, Basın ve Atatürk. İstanbul: Bağlam Yayınları, 140.

[6] Hanioğlu, M. Şükrü (1986). Bir Siyasal Örgüt Olarak Osmanlı İttihat ve Terakki Cemiyeti ve Jön Türklük. İstanbul: İletişim Yayınları, 51-70.

[7] Heper, Metin (1974). Bürokratik Yönetim Geleneği. Ankara: ODTÜ i.I.B.F.D., 94

[8] (2006). Türkiye'de Devlet Geleneği. Ankara: Doğu-Batı Yayınları, 91-92.

[9] Kahraman, H. Bülent (2010). Türk Siyasetinin Yapısal Analizi-I. İstanbul: Agora Yayınları, 29-32.

[10] Kaliber, Alper (2007). "Türk Modernleşmesini Sorunsallaştıran Üç Ana Paradigma Üzerine", Modern Türkiye'de Siyasi Düşünce: Modernleşme ve Batıcılık, Cilt:3, İstanbul: Illetişim Yayınları, 114.

[11] Karpat, Kemal H. (2012). Türk Siyasi Tarihi. İstanbul: Timaş Yayınları, 16.

[12] Keyder, Çağlar (1993). Türkiye'de Din ve Sınıflar. İstanbul: Iletişim Yayınları, 78.

[13] Köker, Levent (1993). Modernleşme, Kemalizm ve Demokrasi. İstanbul: İletişim Yayınları, 131.

[14] Küçükömer, İdris (1994). Düzenin Yabancılaşması: Batılaşma. İstanbul: Bağlam Yayınları, 75.

[15] Lewis, Bernard (1993). Modern Türkiye'nin Doğuşu. Ankara: TTK Yayınları, 200.

[16] Mardin, Şerif (1992). Türk Modernleşmesi. İstanbul: İletişim Yayınları, 306.

[17] Petrosyan, Y.Aşatoviç (1974). Sovyet Gözüyle Jön Türkler. İstanbul: Bilgi Yayınevi, 234-244.

[18] Tanör, Bülent (1999). Osmanlı-Türk Anayasal Gelişmeleri. İstanbul: Yapı Kredi Yayınları, 169.

[19] Tunaya, T. Zafer (2004). Hürriyetin İlanı: İkinci Meşrutiyet'in Siyasi Hayatına Bakışlar. İstanbul: Bilgi Üniversitesi Yayınları, 50. 